\title{
How does Factors Effect on Bank Risk? Evidence from China
}

\author{
Qin Song \& Fangqi HU \& Chuanchuan NI \\ School of Economics \& Business Administration, Central China Normal University, China
}

\begin{abstract}
How does factors effect on bank risk? This paper develops models with a sample of 24 commercial banks in China by measuring risk with Z-score, loan loss reservation ratio and non-performing loan ratio. Capital ratio is negative to bank insolvency probability. Two factors, including liquid ration and bank size, are positive to loan loss reservation ratio and non-performing loan ratio. Other factors, including ROA and banking market concentration, are positive to loan loss reservation ratio. State-owned bank risk is higher than non-State-owned bank risk. GDP growth rate and Realestate price index effects on solvency probability significantly.
\end{abstract}

KEYWORD: Bank risk; Capital regulation; Z-score

\section{INTRODUCTION}

Based on the lessons from the global financial crisis, financial regulators pay more attention to the stability of the banking system and soundness of banking development. Recently, Basel Committee's Basel III regulatory standards revised require banks to raise the minimum capital adequacy, promote the establishment of buffer capital, and introduce minimum standards of global liquidity. The financial regulatory standards will lead to changes in bank risk-taking.

The relationship between Capital regulation and bank risk-taking seems to be no consistent. Capital regulation will lead banks to reconfigure their assets, may increase risk-taking (Koehn and Santomero, 1980). The risk weight corrected in theory will reduce risk-taking (Kim and Santomero, 1988). In some cases, banks are likely to become risk-lovers in limited liability, the minimum capital ratio to ensure that banks take prudent actions (Rochet, 1992). The latest research does not support the strict capital regulation is negative to bank risk-taking. Capital regulation may not reduce bank risk-taking (Laeven and Levin, 2009). Bankruptcy policy should be matched with a strong asset monitoring for failure banks to strictly limit their risk selection. Incentive compatibility of the banking regulatory system, based on moral hazard and adverse selection, may solve the incentive problem and achieve optimal results depending on bank performance (Nagarajan and Sealey, 1998). Appropriate information disclosure and private sector monitoring banks, are also an effective way (Barth, Caprio and Levine, 2004).

How does factors effect on bank risk? The main innovation of this paper is to measuring risk aversion by Z-score. The remainder of this paper is presented as follows. The Section II consists of data and methodology. The Section III discusses empirical results. The Section IV is conclusions.

\section{DATA AND METHODOLOGY}

This paper selects 24 commercial banks from 2004 to 2012, including Industrial \& Commercial Bank of China, Agricultural Bank of China, China Construction Bank, Bank of China, Bank of Communications, China CITIC Bank, China Merchants Bank, China Minsheng Bank, Industrial Bank, Shanghai Pudong Development Bank, Guangdong Development Bank, China Everbright Bank, Bank of Beijing, Hua Xia Bank, Zheshang Bank, Bank of Nanjing, Ping An Bank, Bank of Ningbo, Bank of Shanghai, Hankou Bank, Evergrowing Bank, Huishang Bank, Bank of Jiangsu, and Bank of Bohai. Financial data of 24 banks is from Bankscope. This paper focus on $\operatorname{lnZ}$, Lg, NPLs, TCR, LD, ROA, lnasset, state, stru and $\triangle \mathrm{GDP}$, lnCIV variables as table 1 . 
Table 1 Variable

\begin{tabular}{|c|c|c|}
\hline Variable & Abbreviation & Definition \\
\hline \multirow{4}{*}{ Risk } & LnZ & $\mathrm{Z}=(\mathrm{CAR}+\mu \mathrm{ROA}) / \sigma \mathrm{ROA}$ \\
\cline { 2 - 3 } & $\mathrm{Lg}$ & $\mathrm{Lg}=$ loan loss res/gross loans \\
\hline \multirow{2}{*}{ Capital } & TCR & $\begin{array}{c}\text { TCR=total capital /weighted } \\
\text { risk assets }\end{array}$ \\
\hline \multirow{2}{*}{$\begin{array}{c}\text { Liquidity } \\
\text { Bank }- \\
\text { specific }\end{array}$} & LD & $\begin{array}{c}\text { LD=liquid assets/Dep\&ST } \\
\text { funding }\end{array}$ \\
\cline { 2 - 3 } & ROA & ROA =return/equity \\
\hline \multirow{2}{*}{$\begin{array}{c}\text { Industry } \\
\text { specific }\end{array}$} & State & $\begin{array}{c}\text { Take the natural logarithm of } \\
\text { bank total assets. }\end{array}$ \\
\hline \multirow{2}{*}{$\begin{array}{c}\text { Macroecono-owned bank=1,non- } \\
\text { mics }\end{array}$} & $\Delta$ GDP & $\begin{array}{c}\text { Banking market } \\
\text { stancentration=CR }\end{array}$ \\
\cline { 2 - 3 } & lnCIV & $\begin{array}{c}\text { Take the natural logarithm of } \\
\text { the construction industry } \\
\text { added value }\end{array}$ \\
\hline
\end{tabular}

As can be seen in Table 2, the mean of $\ln Z$ is 2.820 , and the standard deviation value is 0.880 . The mean of loan loss reservation ratio is 83.40 , and the standard deviation value is 41.09 . The mean of the non-performing loan ratio is 75.70 , and the standard deviation value is 49.18. The mean of total capital ratio is 83.83 , and the standard deviation value is52.61. The mean of liquid ratio is 127.3 and the standard deviation value is 65.99 . The mean of loan to deposit ratio is 115.8 and the standard deviation value is66.08. The mean of ROA is 76.22 , and the standard deviation value is 32.10 . The mean of lnasset is 4.530 , and the standard deviation value is 1.030. The mean of dummy variable is 0.170 , and the standard deviation value is 0.380 . The mean of banking market concentration is 0.500 , and the standard deviation value is 0.0300 . The mean of GDP growth rate per year 0.160 , and the standard deviation value is 0.380 . The mean of InCIV is 9.810, and the standard deviation value is 0.470 .

Tables 2 Summary statistics

\begin{tabular}{|c|c|c|c|c|}
\hline Variable & mean & sd & $\min$ & $\max$ \\
\hline $\operatorname{lnZ}$ & 2.820 & 0.880 & 0.420 & 5.420 \\
\hline Lg & 83.40 & 41.09 & 6 & 162 \\
\hline NPLs & 75.70 & 49.18 & 1 & 177 \\
\hline TCR & 83.83 & 52.61 & 1 & 187 \\
\hline LD & 127.3 & 65.99 & 2 & 232 \\
\hline ROA & 76.22 & 32.10 & 2 & 131 \\
\hline lnasset & 4.530 & 1.030 & 0 & 5.530 \\
\hline State & 0.170 & 0.380 & 0 & 1 \\
\hline stru & 0.500 & 0.0300 & 0.450 & 0.540 \\
\hline$\Delta$ GDP & 0.160 & 0.0400 & 0.0900 & 0.230 \\
\hline lnCIV & 9.810 & 0.470 & 9.070 & 10.48 \\
\hline
\end{tabular}

\section{EMPIRICAL RESULTS}

According to variable selected and model setup, the empirical model is as follows:

$$
\begin{aligned}
& \text { Risk }_{i, t}=\beta_{0}+\beta_{1} \text { TCR }_{i, t}+\beta_{2} \text { LD }_{i, t}+\beta_{3} \text { ROA }_{i, t} \\
& +\beta_{4} \ln \text { asset }_{i, t}+\beta_{5} \text { state }+\beta_{6} \text { stru }_{t}+\beta_{7} \Delta G D P_{t} \\
& +\beta_{8} \operatorname{lnCIV}_{t}+\varepsilon_{i, t}
\end{aligned}
$$

We will choose right the model with $\mathrm{F}$ test, BP test, and Hausman test among mixed regressive model, fixed effects model and random effects model.

Table $3 \mathrm{~F}$ test and BP test

\begin{tabular}{|c|c|c|}
\hline Test & F test & BP test \\
\hline risk & \multicolumn{2}{|c|}{ Risk=lnZ, Risk= Lg, Risk=NPLs } \\
\hline results & $\begin{array}{c}\text { Reject mixed regressive } \\
\text { model }\end{array}$ & $\begin{array}{c}\text { Reject mixed } \\
\text { regressive model }\end{array}$ \\
\hline
\end{tabular}

The results of $\mathrm{F}$ test reject mixed regressive model comparing to fixed effects model, and BP test reject mixed regressive model comparing to random effects model from table 3 .

Table 4 Hausman test

\begin{tabular}{|c|c|c|}
\hline Ho & \multicolumn{2}{|c|}{ Difference in coefficients not systematic } \\
\hline & Chi $^{2}$ & $\mathrm{p}>$ chi $^{2}$ \\
\hline Risk=lnZ & 17.13 & 0.0166 \\
\hline Risk= Lg & 2.53 & 0.8651 \\
\hline Risk=NPLs & 3.60 & 0.8247 \\
\hline
\end{tabular}

Notes : chi ${ }^{2}=(\mathrm{b}-\mathrm{B})^{\prime}\left[\left(\mathrm{V} \_\mathrm{b}-\mathrm{V} \_\mathrm{B}\right)^{\wedge}(-1)\right](\mathrm{b}-\mathrm{B}) ; \mathrm{b}=$ consistent under Ho and Ha; obtained from $\mathrm{xtreg} ; \mathrm{B}=$ inconsistent under Ha, efficient under Ho; obtained from xtreg.

Using $\ln Z$ as the proxy variable for risk, the equation rejects random effects model. Using loan loss reservation ratio and non-performing loan ratio as the proxy variable for risk, the equation does not reject random effects model.

Table 5 Coefficients of model

\begin{tabular}{|c|c|c|c|}
\hline & $(1)$ & $(2)$ & $(3)$ \\
\hline Variable & $\ln Z$ & $\mathrm{Lg}$ & NPLs \\
\hline TCR & $0.0021 * *(2.0625)$ & $-0.0201(-0.5136)$ & $0.0307(0.8644)$ \\
\hline LD & $-0.0008(-0.6034)$ & $0.1332 * *(2.5307)$ & $0.1192^{* *}(2.5233)$ \\
\hline ROA & $-0.0038(-1.5441)$ & $0.1891 *(1.6499)$ & $0.0182(0.1724)$ \\
\hline lnasset & $-0.0005(-0.0099)$ & $5.0872 * * *(2.7582)$ & $4.1616 * *(2.5337)$ \\
\hline \multirow{2}{*}{ state } & $-0.4496 * *$ & $35.6931^{* *}$ & $28.2602 * *$ \\
& $(2.2279)$ & $(2.4158)$ & $(2.2208)$ \\
\hline \multirow{2}{*}{ stru } & -7.7214 & $-411.9131^{* *}$ & 128.3899 \\
& $(-1.6212)$ & $(-2.3151)$ & $(0.8059)$ \\
\hline \multirow{2}{*}{$\Delta$ GDP } & $-3.9578^{* * *}$ & -63.4509 & -25.3416 \\
& $(-3.0005)$ & $(-1.2583)$ & $(-0.5606)$ \\
\hline \multirow{2}{*}{ lnCIV } & $1.2504 * * *$ & -14.4135 & $-97.2745 * * *$ \\
& $(4.0825)$ & $(-1.2274)$ & $(-9.2879)$ \\
\hline \multirow{2}{*}{ Constant } & $-4.7641^{* *}$ & $386.2142 * * *$ & $929.1068 * * *$ \\
& $(-2.4058)$ & $(4.8435)$ & $(13.0195)$ \\
\hline
\end{tabular}

Notes : ***,**,* denotes significant $1 \%, 5 \%$, and $10 \%$ level. 
We get several results from table 5. Total capital ratio is positive to $\mathrm{Z}$-score significantly. Liquid ratio is positive to loan loss reservation ratio and nonperforming loan ratio significantly. ROA is positive to loan loss reservation ratio. Bank size is positive to loan loss reservation ratio and non-performing loan ratio. State-owned bank risk is higher than nonState-owned bank risk. Banking market concentration is higher, loan loss reservation ratio bigger. GDP growth rate is negative to bank insolvency probability. Realestate price index is negative to loan loss reservation ratio and nonperforming loan ratio.

\section{CONCLUSIONS}

This paper examines factors effecting on bank risk in China. It develops models with a sample of 24 commercial banks in China by measuring risk with Z-score, loan loss reservation ratio and nonperforming loan ratio. It denotes that the more increase capital ratio greatly, lower solvency probability. However, capital ratio is not significant to loan loss reservation ratio and non-performing loan ratio. Liquid ration and bank size effects on loan loss reservation ratio and non-performing loan ratio, but does not solvency probability. Only loan loss reservation ratio is correlated with ROA positively. Bank Government structure effects on all bank risk variable. Banking market concentration is higher, the smaller loan loss reservation ratio. Macroeconomics variable, including GDP growth rate and Realestate price index effects on solvency probability. With the development of Chinese solvency law, deposit insurance institute and interest rate liberation, more and more commercial banks join in to find how to apply Basel III accords in business, which is helpful for Chinese financial system soundness.

\section{REFERENCES}

[1] Barth, J.R., Caprio, G., \& Levine, R. 2004.Bank Regulation and Supervision: What Works Best, Journal of Finance Intermediary 13 (1): 205-248.

[2] Koehn, M. \& Santomero, A.M. 1980.Regulation of Bank Capital and Portfolio Risk, Journal of Finance 35(2): 12351244.

[3] Kim, D. \& Santomero, A.M. 1988.Risk in Banking and Capital Regulation, Journal of Finance 43 (3):1219-1233.

[4] Laeven,L. \& Levine,R. 2009. Corporate Governance, Regulation and Bank Risk-taking, Journal of Finance Economics 9 (3): 259-275.

[5] Rochet, J.C. 1992.Capital Requirements and the Behavior of Commercial Banks, European Economics Review36 (2): 1137-1178. 